\title{
Democracy, financial openness and global carbon dioxide emissions: Heterogeneity across existing emissions levels
}

\author{
Wan-Hai You ${ }^{\mathrm{a}}$, Hui-Ming Zhu ${ }^{\mathrm{a}, *}{ }^{\text {, Keming Yu }}{ }^{\mathrm{b}}$, Cheng Peng ${ }^{\mathrm{a}}$ \\ ${ }^{a}$ College of Business Administration, Hunan University, Changsha 410082, PR China \\ $b$ School of Information Systems, Computing and Mathematics, Brunel University, London UB8
} $3 P H, U K$

\begin{abstract}
Global warming and Climate change are now widely recognized as two of the most important issues facing human society. Thus, the determinants of $\mathrm{CO}_{2}$ emissions have attracted many researchers over the past few decades. One of the important factors is the democracy level of a country. Most of studies, however, ignore the possibility that effect of democracy on $\mathrm{CO}_{2}$ emissions could vary throughout the $\mathrm{CO}_{2}$ emissions distribution. In this paper, we address this issue by applying panel quantile regression methods. Our results show that the effect of democracy on $\mathrm{CO}_{2}$ emissions is higher heterogeneous across conditional distribution of pollution. The coefficient is highly significant and has the positive sign at lower quantiles. Yet the magnitude decreases toward the higher quantiles and then it becomes insignificant. However, it turns into negative and becomes significant again at the higher quantile. In addition, financial openness is not statistically significant at any quantile. These novel findings not only help advance the existing literature, but also can be of special interest to policy makers.
\end{abstract}

Keywords: $\mathrm{CO}_{2}$ emissions; Democracy; Financial openness; Quantile regression; Panel data.

\section{Introduction}

Global warming has emerged as one of the most challenges facing human society. Greenhouse gas emissions (GHGs), especially carbon dioxide emissions, are considered as a dominant contributor to global warming. Global warming now presents the greatest potential threat to climate change. These increasing environmental threats have led scholars and policy makers to debate over reducing greenhouse gases emissions to alleviate global warming.

\footnotetext{
${ }^{*}$ Corresponding author. Tel./fax: +8673188823670.

E-mail address: zhuhuiming@hnu.edu.cn (H.-M. Zhu).
} 
Many countries have signed the Kyoto Protocol and attempted to decrease greenhouse gas emission to hinder global warming. This in turn calls for a clear identification of the major determinants of $\mathrm{CO}_{2}$ emissions.

Following the seminal work of Grossman and Krueger (1995), a large literature has investigated the relationship between the measure of environmental degradation (such as per capita $\mathrm{CO}_{2}$ emissions) and per capita income under the name of the environmental Kuznets curve (EKC). The EKC hypothesis indicates that environmental degradation initially exaggerates when a country's per capita income is low, as the economy grows, environmental degradation falls. This results in an inverted U-shaped relationship between environmental degradation and income. Thus, it is important to test the validity of the ECK hypothesis when designing appropriate policy tools for fighting against global warming and protecting the environment.

Empirical evidence regarding the EKC hypothesis for $\mathrm{CO}_{2}$ is mixed, as some studies find a linear relationship between $\mathrm{CO}_{2}$ emissions and per capita GDP, others reveal an inverted-U relationship, and yet others find an $\mathrm{N}$-shaped relationship ${ }^{1}$. Several reasons may explain the great discrepancies: the sample used for analysis, the model and the method employed to estimate the relationship, and the control variables included in the model (Zanin and Marra, 2012; Esteve and Tamarit, 2012). While previous empirical studies examine the impact of per capita GDP on per capita emissions, research on the effect of institutional quality is relatively little. More specifically, researchers have usually investigated the determinants of pollution under the STIRPAT (Stochastic Impacts by Regression on Population, Affluence, and Technology) framework (Poumanyvong and Kaneko, 2010; Zhu et al., 2012). The STIRPAT model could be used to assess not only the core components, population size and affluence, on environmental impact, but also other factors like modernization on the environment (York et al., 2003). Martínez-Zarzoso et al. (2007) proxy technology with the share of industry in GDP and energy intensity. Shi (2003) employs the share of industry in GDP and the share of service in GDP as a proxy. In addition, a few studies considered trade openness as additional important variable (Managi et al., 2009; Tsurumi and Managi, 2011).

However, many scholars argue that the relationship between environmental quality and income is not formed in isolation from political institutions that related to the process of

\footnotetext{
1 An excellent literature review, see, for example, He and Richard (2010).
} 
environmental policy making in a country. For example, Dasgupta and Maler (1995) have argued that "The connection between environmental protection and civil and political rights is a close one. As a general rule, political and civil liberties are instrumentally powerful in protecting the environmental resource base, at least when compared with the absence of such liberties in countries run by authoritarian regimes". Therefore, many studies have included the related political variables in the income-pollution relationship (Torras and Boyce, 1998; Barrett and Graddy, 2000).

More recently, some attention has been paid to the relationship between the institutional quality (e.g., democracy) and pollution. Romuald (2011) argues that many environmental problems can be explained by institutional failure and bad government methods. Goel et al., (2013) argue that many policies have been implemented to influence (directly or indirectly) economic agents to internalize environmental externalities. A key factor behind the success of these policies is the institutional quality of a country. In this context of the literature, some researchers have been paid to the democracy-pollution nexus and some researchers have assessed the effect of political freedom on pollution. The results of such studies are, however, contradictory.

Financial openness may also play a significant role in reducing environmental pollution (Tamazian and Rao, 2010; Tamazian et al., 2009; Jalil and Feridun, 2011). However, research on financial openness and its effects on pollution is more recent, and in relative infancy. Thus, our contribution is complementary to this research. We add to the extant literature by: (a) including a broader set of democracy to test the effects of democracy on pollution; (b) by including financial openness, we test the joint importance of democracy and financial openness on pollution. Brune and Guisinger (2003) show that a positive impact of democratic on financial openness. Similarly, Kirch and Terra (2012) argue that financial decisions may be strongly influenced by the institutional quality of a country. Quinn (2000) acknowledges the possibility of reverse causality from financial liberalization to democratic reversals. Given the relationship between democracy and financial openness, if one or both constructs are misrepresented in the model, there is a substantial likelihood that the coefficient of one variable is contaminated by another variable. In order to address this concern, we include both democracy factor and financial openness factor ; (c) by employing a quantile regression model with panel data, notably developed by Koenker (2004), we extend the earlier analysis 
by looking the impact of democracy not only on the mean but also on the shape of the conditional distribution of environmental pollution. At present, only a few, albeit important papers, have applied panel quantile regression fixed effect model to investigate the relationship between income and pollution (Damette and Delacote, 2012; Flores et al., 2013; Yaduma et al., 2013) $)^{2}$. This method allows us to derive different parameter estimates for various conditional quantiles of pollution. Furthermore, quantile regressions model with fixed effects improve the usual cross-sectional or panel pooled data regressions by exploring simultaneously two kinds of heterogeneity: unobserved individual heterogeneity via fixed effects and common heterogeneity via covariates effects within the panel quantile estimation (Damette and Delacote, 2012). To test the robustness of our results, we also employ the method proposed by Canay (2011) to estimate the panel quantile regression model. To the best of our knowledge, no paper investigates the joint role of economic, financial and democracy variables on $\mathrm{CO}_{2}$ emissions in the panel quantile regression model framework. From a policy perspective, it is more interesting to understand what happens at the extremes of a distribution. For example, Chestnut et al., (1991) argue that both humans and ecosystems are more seriously affected at high concentrations of pollutions. Hence, it is important to learn about the behavior of emissions at high levels of pollution. In the type of consideration, the focus is no longer on the mean effect, but on the full distribution of pollution emissions.

The remainder of the paper is organized as follows. Section 2 of the paper we review previous literature while Section 3 outlines the methodology used within this paper. Section 4 we describe the data used in this paper. The empirical results of panel quantile regression models are presented in Section 5. Section 6 concludes the paper.

\section{Literature review}

There are a number of studies that investigate the link between institutional quality and pollution. On the whole, this branch of research can be categorized into two strands. The first strand of the literature investigates the democracy-environmental pollution nexus. The second strand of the literature examines the corruption-environmental pollution nexus. In this paper we mainly focus on the democracy-environmental pollution nexus. Some theorists believe

\footnotetext{
${ }^{2}$ These papers, however, have not included explanatory variables to explicitly account for the role of democracy in the income-environmental nexus.
} 
that democracy can improve the environmental quality of a country, while others argue that may not improve the environmental quality or may even worsen it. Empirically, the results are mixed. The studies by Torras and Boyce (1998), Barrett and Graddy (2000), Li and Reuveny (2006), and Farzin and Bond (2006) argue that democratization makes citizens better informed and better enabled to protest. Torras and Boyce (1998) find that democracy, proxied by the Freedom House indicators of political rights and civil liberties in 1995, has in general a positive and significant effect on environmental quality, especially in low-income countries. Harbaugh et al. (2002) find there exist a consistent negative relationship between sulphur dioxide and the democracy level of a country. Using a panel data model over the 1980-1998 period, Farzin and Bond (2006) find evidence that the country's level of democracy (based on Polity IV data) and its associated freedoms is related positively to environmental quality. Using a panel dataset of 107 cities in 42 countries over the period 1971-1996, Bernauer and Koubi (2009) find that democracies and especially presidential systems have a positive effect on air quality.

However, several scholars find that democracy may not improve the environmental quality or may even worsen it (Midlarsky, 1998; Roberts and Parks, 2007; Scruggs, 1998). For example, Roberts and Parks (2007) conclude that democracy has almost no impact on carbon emissions. Scruggs (1998) also find an insignificant relationship between democracy level and three environmental indicators (dissolved oxygen demand, fecal coliform, particulates emissions), once income inequality is included. Nevertheless, Midlarsky (1998) finds that a higher democracy level is associated with a worse environmental performance. The author argues that democratic governments may not be responsive to environmental imperatives because some groups are expected to lose (or gain) more than others when environmental policies are implemented.

Though many literature concerned with the relationship between democracy and environmental quality, it is safe to say that extant empirical evidence on democracy-pollution nexus is mixed. We argue that the main shortcoming of these studies is that the result may be biased due to neglect the distributional heterogeneity. In addition, only a few studies explicitly assess the impact of financial openness on pollution (Tamazian and Rao, 2010; Tamazian et al., 2009; Jalil and Feridun, 2011). Frankel and Rose (2005) argue that openness is at least as likely to help the environment as to hurt it. Therefore, such an improvement in financial 
infrastructure (based on the openness of capital account) may contribute to the efficient technological use and, therefore affect the environmental degradation as well (Tamazian et al., 2009). So far we have found little empirical work to establish the relationships between democracy, financial openness, and environmental pollution accounting for distributional heterogeneity. To achieve insight into the unobserved individual heterogeneity and distributional heterogeneity, a further study on the impact of democracy on pollution with panel quantile regression with fixed effect model is necessary.

\section{Methodology}

In this paper we employ the panel quantile model with fixed effect to investigate the impact of economic, financial openness, and democracy on environmental quality. While the usual regressions focus on the mean, quantile regression is able to describe the entire conditional distribution of the dependent variable (emissions). Using this methodology, we are able to assess the determinants of emissions throughout the conditional distribution, with particular focus on the most and least emissions countries-those that arguably of the most interest. Quantile regression can therefore help us obtain a more complete picture of the factors affecting emissions. Indeed, focusing on the mean effects may under- or overestimate the relevant coefficient estimates, or may even fail to detect important relationships (Binder and Coad, 2011).

Quantile regressions, first introduced in the seminal paper by Koenker and Bassett (1978), is a generalization of median regression analysis to other quantiles. The $\tau$ th quantile of the conditional distribution is estimated by solving:

$$
\min \sum_{i=1}^{n} \rho_{\tau}\left(y_{i}-x_{i}^{T} \beta\right),
$$

where $\rho_{\tau}(u)=u(\tau-I(u<0))$ is the "check function"; I(.) is an indicator function. The conditional quantile of $y_{i}$ given $x_{i}$ is

$$
Q_{y_{i}}\left(\tau \mid x_{i}\right)=x_{i}^{T} \beta_{\tau},
$$

From (1) we can see that quantile regression can be seen to be a weighted regression. For example, if $\tau=0.6$, the negative residuals will have less weight than the positive ones. Thus, unlike standard regression estimator, quantile regression estimators are robust to outliers and 
distributions with heavy tails. It is worth mentioning that segmenting the dependent variable into subsets according to its unconditional distribution and then running an OLS on these subsets is not an appropriate alternative to the quantile regression, due to severe sample selection problems (Koenker and Hallock, 2001).

Quantile regression is first introduced as a cross-sectional estimator (Koenker and Bassett, 1978). However, these estimators do not take into account unobserved country heterogeneity. To combine the advantages of quantile regression model with panel data, there has been little but growing work have focused on the econometric theory of applying quantile regression to panel data contexts, such as Koenker (2004), Lamarche (2010), Galvao and Montes-Rojas (2010), Galvao (2011) and Canay (2011). Consider panel quantile regression model with fixed effects as

$$
Q_{y_{i t}}\left(\tau_{k} \mid \alpha_{i}, x_{i t}\right)=x_{i t}^{\prime} \beta\left(\tau_{k}\right)+\alpha_{i},
$$

The main problem with panel quantile regression with fixed effect is that the inclusion of a large number of fixed effects $\left(\alpha_{i}\right)$ lparameter incidental parameters problem. The estimator will be inconsistent when the number of cross-sectional units goes to infinity while the number of observations for each cross-sectional unit is fixed (Kato and Galvao, 2010). The standard demeaning (or differencing) approachs to eliminate unobserved fixed effects is unfeasible in the quantile regression model. These methods rely on the fact that expectations are linear operators, which is not the case for conditional quantiles (Canay, 2011). That is also the main reason why the literature about panel quantile regression with fixed effect is relatively little.

Koenker (2004) proposes a method (called shrinkage method) to deal with such problem. The author treats unobservable fixed effect as parameters to be jointly estimated with the covariate effects for different quantiles. Specifically, parameter estimators are obtained by solving the following expression:

$$
\min _{\alpha, \beta} \sum_{k=1}^{K} \sum_{t=1}^{T} \sum_{i=1}^{N} w_{k} \rho_{\tau_{k}}\left(y_{i t}-\alpha_{i}-x_{i t}^{T} \beta\left(\tau_{k}\right)\right)+\lambda \sum_{i=1}^{N}\left|\alpha_{i}\right|,
$$

where $w_{k}$ is the relative weight given to the $k$-th quantile, which controls for the contribution of the $k$-th quantile on the estimation of the fixed effects. In this paper we employ equally weighted quantiles $w_{k}=1 / K$ (Lamarche, 2011; Alexander et al., 2011). $\lambda$ is the tuning parameter that shrinks the individual effects toward zero to improve the 
performance of the estimate of $\beta$. For the term $\lambda$ goes to zero, the penalty term disappears and we obtain the usual fixed effect estimator, while the term goes to infinite, we obtain the estimate of the model without the individual effects (Pooled model). In this paper we set $\lambda=1$ as Damette and Delacote (2012) and Lee et al., (2012). To check the robustness of our results, we also conduct sensitivity analysis with different value of $\lambda$.

Canay (2011) finds that Koenker's method is computationally intensive and the author develops a two-step method of estimating panel quantile regression model with fixed effects. Canay proposes a simple transformation of the data that eliminates the individual fixed effects under the assumption that these effects are location shifters (fixed effects are constant across quantiles). Given this assumption, Canay develops the following two-step procedure. First, estimates the standard fixed effect panel data model at the conditional mean and then employing the estimated parameters to obtain the individual fixed effect $\hat{\alpha}_{i}$. Second, subtracts this component from the dependent variable $\left(\hat{y}_{i t}=y_{i t}-\hat{\alpha}_{i}\right)$ and proceeds using the standard method of estimation of quantile regression. Furthermore, the bootstrap method is employed to obtain the variance-covariance matrix for this estimator ${ }^{3}$. The bootstrap method is based on randomly drawn samples (with replacement) of size $N T$ from the original data. For each of these $B$ draws, the two-step estimator as described above is computed and resulting in $B$ different estimates for $\hat{\beta}_{b}^{*}(\tau)=\left(\hat{\beta}_{1 b}^{*}(\tau), \cdots, \hat{\beta}_{k b}^{*}(\tau)\right)^{\prime}, b=1, \cdots, B$.Therefore, the estimated bootstrapped variance- covariance matrix at quantile $\tau$ is constructed as

$$
\frac{1}{B} \sum_{b=1}^{B}\left(\hat{\beta}_{b}^{*}(\tau)-\bar{\beta}^{*}(\tau)\right)\left(\hat{\beta}_{b}^{*}(\tau)-\bar{\beta}^{*}(\tau)\right)^{\prime}
$$

where $\bar{\beta}^{*}(\tau)=\frac{1}{B} \sum_{b=1}^{B} \hat{\beta}_{b}^{*}(\tau)$

In this paper we study the effect of democracy on environmental quality by modifying the specification of previous studies to account for heterogeneity throughout the pollution distribution. We specify the conditional quantile function for quantile $\tau$ (such as the 10th,20th,..., 90th, 95th percentiles) as follow

$Q_{y_{i t}}\left(\tau \mid \alpha_{i}, x_{i t}\right)=\alpha_{i}+\xi_{t}+\beta_{1 \tau} G D P_{i t}+\beta_{2 \tau} P O P_{i t}+\beta_{3 \tau} T R A D E_{i t}+\beta_{4 \tau} I N D U S_{i t}+\beta_{5 \tau}$ democ $_{i t}+\beta_{6 \tau}$ Kaopen $_{i t}$

\footnotetext{
3 The bootstrap procedure usually performs well in the calculation of covariance matrix estimates and confidence intervals (Buchinsky, 1998).
} 
where the countries are indexed by $i$ and time by $t . y_{i t}$ is emissions indicator and we using per capita $\mathrm{CO}_{2}$ emissions (metric tons per capita); GDP is measured by the GDP per capita; $P O P$ denotes population size; TRADE represents trade openness, proxied by exports plus imports as a percentage of GDP; INDUS is the share of industry sector in GDP; Kaopen is collected from Chinn and Ito (2008); democ is democracy indicator and we use polity meansure (Polity2) and Freedom House Political Rights Index and Civil Liberties Index (see section 4 for details). Depending on the democracy indicator used, the sample size is 87 and 97 countries $^{4}$.

\section{Data description and analysis}

In this paper we attempt to investigate the relationship between democracy, financial openness, and environmental quality using data from a cross-section of countries over the time span from 1985-2005. The choice of sample selected for this analysis is primarily dictated by the availability of reliable data. The dependent variable in this analysis is $\mathrm{CO}_{2}$ emissions. As mentioned earlier, $\mathrm{CO}_{2}$ emissions are considered as the primary greenhouse gas responsible for global warming (IPCC, 2007). Our source of $\mathrm{CO}_{2}$ emission data is the World Bank (2013). Next, we will discuss the main explanatory variables chosen for our analysis, as well as control variables.

Our main variable of interest is democracy. Buitenzorgy and Mol (2011) point out that democracy is not an easy variable to measure. The most widely used democracy indices for measuring the democracy level of a country are the Polity index (Marshall and Jaggers, 2012) and the Freedom House index (Freedom House, 2011). We use a broad array of democracy measures in this paper. The first democracy variable used is the aggregate indicator of democracy from the Polity IV database (polity2) (Marshall and Jaggers, 2012). This variable captures the regime authority spectrum on a 21-point scale ranging from -10 (fully non-democratic) to +10 (fully democratic). As a robustness check, an alternative measure of democracy is used. The second democracy is the Freedom House Political Rights Index and Civil Liberties Index, which assigns a numerical value to each country on a scale of 1-7, where 1 indicating the highest degree of freedom and 7 the lowest degree of freedom. For the

\footnotetext{
${ }^{4}$ The list of countries is provided in Appendix A.
} 
purpose of simplifying the interpretation, the Freedom House Political Rights Index is reversed (by subtracting each value from 8) so that 7 now represents the highest level of democracy and 1 the lowest level. We use a simple sum of these two indices as a proxy for the aggregate democracy level.

To measure financial openness, we use the Chinn and Ito (2008) index (so called kaopen index), which is one of the most commonly used indices in the literature. This index is constructed based on the data from the IMF Annual Report on Exchange Arrangements and Exchange Restrictions (AREAER). It ranges between-2. 66 (full capital controls) and 2.66 (complete liberalization).

Because the relationship between environmental quality and democracy can be affected by other factors, it is desirable to adopt a multivariate approach to avoid an omitted variable bias. According to the previous literature, a vector of additional explanatory variables included in the model. These include trade openness, population size, and the share of industry in the country's GDP, as it is common in the EKC literature. Trade openness is measured by the ratio of annual imports plus exports to GDP. Population size is the total population of a country. These variables capture the economic and demographic structure of countries which are expected to influence their pollution profile. These three variables collected form WDI (2013). Aside from these variables, we also include country dummies and year dummies. The justification for adding country dummies notes that they account for any remaining time-invariant country specific variation is not captured by our measure of main variables, whose omission could bias the estimates in a typical cross-sectional study. Finally, year dummies are used in order to control for common time shocks to all countries. Following the standard practice, all the variables enter the regression in natural log form except democracy, financial openness as well as country and time dummies. Details about the data and its sources are provided in Table 1.

\section{[Insert Table 1 about here]}

Table 2 presents an overview of the descriptive statistics and pairwise correlations between our main variables of interest. The histograms showing the distribution of $\mathrm{CO}_{2}$ emissions are shown in Fig. 1. Clearly, the distribution of $\mathrm{CO}_{2}$ is skewed. In heterogeneous distribution, the OLS regression estimates the mean effect of the independent variables on dependent variable might seriously under- or over-estimate effects or even fail to identify 
effects at all (Cade and Noon, 2003). A solution to such problem is to employ the quantile regressions method instead of OLS regressions (Koenker and Bassett, 1978). Quantile regressions method makes it possible to analyze effects of the independent variables on different quantiles of the pollution distribution instead of focus on the mean of the distribution. In addition, the method is robust to outlier and gives the researcher a more complete picture of the effects of the independent variables on the dependent variable (Binder and Coad, 2011). While the quantile regressions are starting to be recognized as a helpful technique in the case of skewed distributions in other fields of economics, there are relative few studies that have applied it in the area of environmental science (Flores et al., 2013). We therefore use a quantile regression model to estimate the relationship between environmental quality and democracy in the following section.

\section{[Insert Table 2 about here] \\ [Insert Fig.1 about here ]}

\section{Empirical results}

In this section we report and discuss our empirical results. As a benchmark, we first present pooled and fixed effects OLS regression estimates. Second, we focus on the main results of this paper, with an eye toward shedding light on the question: whether the effect of democracy and financial openness on pollution heterogeneous along quantiles of the conditional distribution of pollution. Finally, we discuss our robustness checks, showing whether our empirical results vary according to alternative estimation procedures and alternative model specifications.

\subsection{Main results}

Before estimating the panel quantile regression models, we test whether the variables used are stationary. The results show that all the variables are stationary in levels ${ }^{5}$. Therefore, we

\footnotetext{
587 countries with Polity measure. For $\mathrm{CO}_{2}$, gdp, trade openness, population size, the share of industry in gdp, democracy, financial openness, the t-bars (P value) of Im et al., (2003) (IPS) test are -5.0962 (0.0000), -3.4034 (0.0003), -7.3499(0.0000), -1.4834 (0.0690), -4.4030 (0.0000), -12.5368 (0.0000) and -3.6471 (0.0001), respectively; 97 countries with Freedom House measure, the $t$-bars ( $P$ value) of Im et al., (2003) (IPS) test are -4.7746 (0.0000), -3.8590 (0.0001), -7.6522 (0.0000), -2.4064 (0.0081),-4.7765 (0.0000),-1.3917 (0.0820) and $-3.9282(0.0000)$, respectively. Linear trend term included. The maximum lag lengths are set to 5 and Schwarz
} 
proceed with panel quantile regression model.

To facilitate a comparison, the model is estimated first by pooled and fixed effects OLS regression estimates. Columns 1 and 2 in Table 3 present the pooled and one-way individual fixed effects OLS regression estimates, respectively. Most variables tend to increase and decrease together in different regions over time (e.g. along the business cycle). As pointed by Baltagi (2008), time-period fixed effects control for all time specific, spatial-invariant variables whose omission could bias the estimates in a typical time series study. Thus, we focus our discussion on the results with respect to the model with two-way fixed effect. To control for such effect, Columns 3 reports the results of two-way fixed effects. The mixed results from these model specifications are in line with previous findings. Only the effect of income is consistent across specifications.

\section{[Insert Table 3 about here]}

To control for the distributional heterogeneity, quantile regression with fixed effects of Koenker (2004) is used. As indicated above, omission time-period fixed effects could bias the estimates in a typical time series study. This is the source of motivation for our focus on quantile regression analysis with two-way fixed effect. Table 4 presents our panel quantile regression estimation results regarding the impact of two measures of democracy, Polity IV measure and Freedom House measure, on pollution for the 1985-2005 period, respectively. The results are reported for the $10,20,30,40,50,60,70,80,90,95$ th percentiles of the conditional pollution distribution. The standard errors for the quantile estimates are obtained by bootstrapping approach. From Panel (A) of Table 4, we can see that the impact of democracy on pollution is highly heterogeneous. There is some pronounced differences across different percentiles in the conditional distribution of pollution. The coefficient is highly significant and has the positive sign at lower quantiles. Yet the magnitude decreases toward the higher quantiles. At the 60th quantile it becomes insignificant and then turns into negative and becomes significant again at the 95th quantile.

\section{[Insert Table 4 about here]}

Nevertheless, the coefficient of democracy is significant and positive in the OLS mean 
regression with two-way fixed effect. One possible explanation is that our results are corrected for distributional heterogeneity, which might decreases the likelihood of under- or overestimate the relevant coefficient estimates. Also, the results provide evidence for our claim that OLS mean regression only provides an incomplete picture about the effect of democracy on pollution. Our results indicate that democracy is negatively related to pollution for the 95th percentile, imply that higher democracy level appear to represent an incentive for environmental protect in high pollution countries. With respect to the main focus of this paper, financial openness is not statistically significant at various percentiles. Therefore, this cannot support the hypothesis that the degree of financial openness of a country is associated with pollution. From the later discussion we can conclude that this result is robust to different specifications.

Results for other control variables included in the model are also informative. We can conclude that the effect of income (per capita GDP) and population size are consistent across quantiles. Greater economic prosperity and larger population size lead to higher pollution emissions. Thus, the results suggest little evidence of heterogeneity in the effects of GDP and population size on pollution, though the marginal impact is differenct across conditional distributional of pollution. The coefficient on the share of industry in GDP is insignificant for 10th and 20th percentiles but positive and significant for the other percentiles. It is worthwhile noting that the marginal impact of this variable increases for high pollution countries. The impact of trade openness is positive, although insignificant at various percentiles. That is to say that we do not find any significant effect of trade openness on pollution. To sum up, we find that, on average, the control variables are largely similar to those when using OLS in terms of sign.

In the analysis above, we use the Polity IV database measure of democracy (Marshall and Jaggers, 2012). As a robustness check, we use an alternative measure of democracy, compiled annually by Freedom House based on an assessment of political rights and civil liberties. Panel (B) of Table 4 reports the results of estimating Eq. (6) using alternative democracy variable, taken from the Freedom House index (Freedom House, 2011). The results are largely similar to Table 3. The impact of democracy on pollution is highly heterogeneous. Financial openness is found to statistically insignificant. The effects of economic prosperity and population size are consistent throughout the conditional distribution of pollution. We find 
that economic prosperity and population size have a strong and positive impact on pollution emissions.

\subsection{Robustness checks}

In order to test the validity of our results, we conduct a series of robustness checks in the following section. These include considering: (i) an alternative estimation technique; (ii) nonlinearities in the effect of GDP; (iii) different values for $\lambda$.(iv) Alternative model specification.

\subsubsection{Alternative estimation techniques}

In the main analysis above, we use the estimation method proposed by Koenker (2004). In this section we investigate whether our findings are affected by different estimation techniques. We report the results of Canay (2011) method in Table 5. We find that the impact of democracy on pollution is higher heterogeneous. Financial openness is found to statistically insignificant at various quantiles of the conditional distribution. Among these additional controls, we find that economic prosperity and population size have a positive and statistically significant impact on pollution, largely consistent with the above findings.

\section{[Insert Table 5 about here]}

\subsubsection{Nonlinearities in the effect of GDP}

To account for possible nonlinear relationship between economic prosperity and pollution, we include GDP squared term in the explanatory variables set. The corresponding regression results are reported in Table 6 . As the results of Table 6 demonstrate, population size significantly positively correlated with pollution. Coefficient of Financial openness is insignificant throughout the distribution. More importantly, the impact of democracy on pollution also is higher heterogeneous, consistent with the above findings. This gives us confidence that it is vital to take into account distributional heterogeneous of pollution.

\section{[Insert Table 6 about here]}

\subsubsection{Different values for $\lambda$}

Next, we investigate whether our findings are robustness to different $\lambda$. We experiment with different values of $\lambda$ range from 0.1 to 1.5 . The control variables are largely similar to those when using $\lambda=1$. To save space, We only report the main variables of interest. The 
results are reported in Table 7 and Table 8 . The findings are almost consistent with those from panel quantile regression results with $\lambda=1$.

\section{[Insert Table 7 about here]}

\section{[Insert Table 8 about here]}

\subsubsection{Alternative model specification}

Up to this point, all the regression results provided above have included both democracy and financial openness. Brune and Guisinger (2003) show that a positive impact of democratic on financial openness. Similarly, Kirch and Terra (2012) argue that financial decisions may be strongly influenced by the institutional quality of a country. Quinn (2000) acknowledges the possibility of reverse causality from financial liberalization to democratic reversals. Given the relationship between democracy and financial openness, if one or both constructs are misrepresented in the model, there is a substantial likelihood that the coefficient of one variable is contaminated by another variable. Therefore, we run two other model specifications. Specification I includes only democracy level and specification II includes only financial openness. As the results of Table 9 and Table 10 demonstrate, the findings are similar to the model specification include both factors.

\section{[Insert Table 9 about here]}

\section{[Insert Table 10 about here]}

Overall, the results from these various robustness checks largely support the robustness of the previous findings. The effect of democracy is higher heterogeneous across different percentiles in the conditional distribution of pollution. Our finding that financial openness is not statistically significant at any quantile. Coefficients for other control variables are similar to the results reported above and do not seem to be sensitive to a particular estimation procedure, an alternative measure of democracy. Thus, we conclude that the results reported in this paper are robust

\section{Conclusions}

The objective of this study is to explore the impact of democracy on pollution using the panel quantile regression model, which takes into consideration unobserved individual 
heterogeneity and distributional heterogeneity. Quantile regression model can obtain a full picture of the relationship between pollution and democracy across the whole distribution of the former, not just for its mean value. While the democracy-pollution nexus have drawn economists' interest in recent years, the main contribution of this study is to examine the sensitivity of the democracy-pollution nexus to the conditional distribution of pollution. Also, we believe that quantile regression model can help us obtain a more complete picture of the factors affecting emissions.

In general, we find that economic prosperity and population size have a positive and significant effect on pollution. We do not find any significant effect of trade openness on pollution. Our most important finding, however, is that the impact of democracy on pollution is not uniform across conditional distribution of pollution. The coefficient is highly significant and has the positive sign at lower quantiles. Yet the magnitude decreases toward the higher quantiles and then it becomes insignificant. However, it turns into negative and becomes significant again at the higher quantile. This gives the insights that the democracy-pollution nexus may have been not fully studied in previous studies that focused on mean effects. Another key implication of our findings is that financial openness has not significant effect on pollution at any quantile. Our main findings are generally robust when the alternative estimation methods and alterntvie model specifications are employed.

\section{Acknowledgments}

The authors would like to thank Stefan Holst Bache for endless support and patience. We also thank Canay for providing R codes of his method. This research is partially supported by the National Natural Science Foundation of China under grants No. 71171075, No. 71221001, and No. 71031004. W-H You expresses thanks for the partial support from the Hunan Provincial Innovation Foundation for Postgraduate (No. CX2013B127). All remaining errors are ours.

\section{References}

Alexander, M., Harding, M.,Lamarche, C. (2011). Quantile Regression for Time-Series-CrossSection Data. International Journal of Statistics and Management System, 6 (1-2), 47-72.

Baltagi, B. (2008). Econometric analysis of panel data. John Wiley \& Sons. 
Barrett, S., Graddy, K., (2000). Freedom, growth, and the environment. Environment and Development Economics 5 (4): 433-456

Bernauer, T., Koubi, V. (2009). Effects of political institutions on air quality. Ecological Economics, 68 (5), 1355-1365.

Binder, M., Coad, A. (2011). From Average Joe's happiness to Miserable Jane and Cheerful John: using quantile regressions to analyze the full subjective well-being distribution. Journal of Economic Behavior \& Organization, 79 (3), 275-290.

Brune, N. and A. Guisinger, 2003, The diffusion of capital account liberalization in developing countries. Unpublished manuscript, UCLA and University of Notre Dame.

Buitenzorgy, M., Mol, A. P. (2011). Does democracy lead to a better environment? Deforestation and the democratic transition peak. Environmental and resource economics, 48 (1), 59-70.

Buchinsky, M. (1998). Recent Advances in Quantile Regression Models: A Practical Guideline for Empirical Research. Journal of human resources, 33 (1).

Cade, B. S., Noon, B. R. (2003). A gentle introduction to quantile regression for ecologists. Frontiers in Ecology and the Environment, 1 (8), 412-420.

Canay, I. A. (2011). A simple approach to quantile regression for panel data. The Econometrics Journal, 14 (3), 368-386.

Chestnut, L. G., Schwartz, J., Savitz, D. A., Burchfiel, C. M. (1991). Pulmonary function and ambient particulate matter: epidemiological evidence from NHANES I. Archives of Environmental Health: An International Journal, 46 (3), 135-144.

Chinn, M. D., Ito, H. (2008). A new measure of financial openness. Journal of Comparative Policy Analysis, 10 (3), 309-322.

Damette, O., Delacote, P. (2012). On the economic factors of deforestation: What can we learn from quantile analysis?. Economic Modelling, 29 (6), 2427-2434.

Dasgupta, P., Maler, K.G., 1995. Poverty, institutions, and the environmental resource-base. In: Behrman, J., Srinivaan, T.N. (Eds.), Handbook of Development Economics, vol. 3A. Elsevier Science, Amsterdam.

Esteve, V., Tamarit, C. (2012). Is there an environmental Kuznets curve for Spain? Fresh evidence from old data. Economic Modelling, 29 (6), 2696-2703.

Farzin, Y. H., Bond, C. A. (2006). Democracy and environmental quality. Journal of Development Economics, 81 (1), 213-235.

Flores, C. A., Flores-Lagunes, A.,Kapetanakis, D. (2013). Lessons from Quantile Panel Estimation of the Environmental Kuznets Curve. Econometric Reviews, (just-accepted).

Frankel, J. A., Rose, A. K. (2005). Is trade good or bad for the environment? Sorting out the 
causality. Review of Economics and Statistics, 87 (1), 85-91.

Freedom House, 2011.Freedom in the world. www.freedomhouse.org/ ratings/index.htm

Galvao Jr, A. F. (2011). Quantile regression for dynamic panel data with fixed effects. Journal of Econometrics, 164 (1), 142-157.

Galvao, A. F., Montes-Rojas, G. V. (2010). Penalized quantile regression for dynamic panel data. Journal of Statistical Planning and Inference, 140 (11), 3476-3497.

Goel, R. K., Herrala, R., Mazhar, U. (2013). Institutional quality and environmental pollution: MENA countries versus the rest of the world. Economic Systems, 37 (4), 508-521.

Grossman, G. M., Krueger, A. B. (1995). Economic growth and the environment. The Quarterly Journal of Economics, 110 (2), 353-377.

Harbaugh, W. T., Levinson, A., Wilson, D. M. (2002). Reexamining the empirical evidence for an environmental Kuznets curve. Review of Economics and Statistics, 84 (3), 541-551.

He, J., Richard, P. (2010). Environmental Kuznets curve for $\mathrm{CO}_{2}$ in Canada. Ecological Economics, 69 (5), 1083-1093.

Im, K. S., Pesaran, M. H., \& Shin, Y. (2003). Testing for unit roots in heterogeneous panels. Journal of Econometrics, 115 (1), 53-74.

Intergovernmental Panel on Climate Change, 2007. Working Group III Report: Mitigation of Climate Change. http://www.ipcc.ch/publications_and_data/ar4/wg3/en/contents.html

Jalil, A., Feridun, M. (2011). The impact of growth, energy and financial development on the environment in China: A cointegration analysis. Energy Economics, 33 (2), 284-291.

Kato, K., Galvao, A. F. (2010). Smoothed quantile regression for panel data. Discussion paper, University of Iowa.

Kirch, G., Terra, P. R. S. (2012). Determinants of corporate debt maturity in South America: Do institutional quality and financial development matter? Journal of Corporate Finance, 18 (4), 980-993.

Koenker, R. (2004). Quantile regression for longitudinal data. Journal of Multivariate Analysis, 91 (1), 74-89.

Koenker, R., Bassett, G.J., 1978. Regression quantiles. Econometrica 46, 33 - 50.

Koenker, R., Hallock, K.F., 2001. Quantile regression. Journal of Economic Theory 15, 143 - 156.

Lamarche, C. (2010). Robust penalized quantile regression estimation for panel data. Journal of Econometrics, 157 (2), 396-408.

Lamarche, C. (2011). Measuring the incentives to learn in Colombia using new quantile regression approaches. Journal of Development Economics, 96 (2), 278-288.

Lee, J. S., Huang, G. L., Kuo, C. T., Lee, L. C. (2012). The momentum effect on Chinese real 
estate stocks: Evidence from firm performance levels. Economic Modelling, 29 (6), $2392-2406$

Li, Q., Reuveny, R. (2006). Democracy and environmental degradation. International studies quarterly, 50 (4), 935-956.

Managi, S., Hibiki, A., Tsurumi, T. (2009). Does trade openness improve environmental quality?. Journal of environmental economics and management, 58 (3), 346-363.

Marshall MG, Jaggers K (2012) Polity IV project: political regime characteristics and transitions, 1800-2012. University of Maryland. http://www.systemicpeace.org/inscr/inscr.htm

Martínez-Zarzoso, I., Bengochea-Morancho, A., Morales-Lage, R. (2007). The impact of population on $\mathrm{CO}_{2}$ emissions: evidence from European countries. Environmental and Resource Economics, 38 (4), 497-512.

Midlarsky, M. I. (1998). Democracy and the environment: an empirical assessment. Journal of Peace Research, 35 (3), 341-361.

Poumanyvong, P., Kaneko, S. (2010). Does urbanization lead to less energy use and lower $\mathrm{CO}_{2}$ emissions? A cross-country analysis. Ecological Economics, 70 (2), 434-444.

Quinn, D. P. (2000). Democracy and international financial liberalization. McDonough School of Business, Georgetown University.

Roberts, J. T., Parks, B. C. (2007). A climate of injustice: Global inequality, north-south politics, and climate policy. MIT Press, Cambridge (Mass)

Romuald, K. S. (2011). Democratic Institutions and Environmental Quality: Effects and Transmission Channels. In 2011 International Congress, August 30-September 2, 2011, Zurich, Switzerland (No. 120396). European Association of Agricultural Economists.

Scruggs, L. A. (1998). Political and economic inequality and the environment. Ecological Economics, 26 (3), 259-275.

Shi, A. (2003). The impact of population pressure on global carbon dioxide emissions, 1975-1996: evidence from pooled cross-country data. Ecological Economics, 44 (1), 29-42.

Tamazian, A., Bhaskara Rao, B. (2010). Do economic, financial and institutional developments matter for environmental degradation? Evidence from transitional economies. Energy Economics, 32 (1), 137-145.

Tamazian, A., Chousa, J. P., Vadlamannati, K. C. (2009). Does higher economic and financial development lead to environmental degradation: evidence from BRIC countries. Energy Policy, 37 (1), 246-253

Torras, M., Boyce, J. K. (1998). Income, inequality, and pollution: a reassessment of the environmental Kuznets curve. Ecological economics, 25 (2), 147-160. 
Tsurumi, T., Managi, S. (2011). The effect of trade openness on deforestation: empirical analysis for 142 countries. Environmental Economics and Policy Studies, 1-20.

Yaduma, N., Kortelainen, M., Wossink, A. (2013). The Environmental Kuznets Curve at Different Levels of Economic Development: A Counterfactual Quantile Regression Analysis for $\mathrm{CO}_{2}$ Emissions (No. 1322). Economics, The University of Manchester.

York, R., Rosa, E. A., Dietz, T. (2003). STIRPAT, IPAT and ImPACT: analytic tools for unpacking the driving forces of environmental impacts. Ecological economics, 46 (3), 351-365.

Zanin,L.,Marra.2012. Assessing the functional relationship between $\mathrm{CO}_{2}$ emissions and economic development using an additive mixed model approach. Economic Modelling.29 (4): 1328-1337.

Zhu, H. M., You, W. H., Zeng, Z. F. (2012). Urbanization and $\mathrm{CO}_{2}$ emissions: A semi-parametric panel data analysis. Economics Letters, 117 (3), 848-850. 


\section{Table 1}

Variable definitions and data sources.

\begin{tabular}{|c|c|c|}
\hline Variable & Definition & Source \\
\hline $\mathrm{CO}_{2}$ & Carbon dioxide emissions (metric tons per capita) & World Development Indicators, $2013^{\mathrm{d}}$ \\
\hline GDP & GDP per capita (constant 2005 US\$) & World Development Indicators, 2013 \\
\hline POP & Population size & World Development Indicators, 2013 \\
\hline TRADE & Ratio of imports plus exports to GDP & World Development Indicators, 2013 \\
\hline INDUS & The share of industry in GDP & World Development Indicators, 2013 \\
\hline Polity2 & The difference between the sub-indexes for democracy and autocracy & Marshall and Jaggers (2012) ${ }^{a}$ \\
\hline Freedom & Sum of the Freedom House Political Rights and Civil Liberties Indices & Freedom House (2011) ${ }^{b}$ \\
\hline Kaopen & Financial openness measuring the extent of openness in capital account transactions & Chinn and Ito (2008) ${ }^{c}$ \\
\hline
\end{tabular}

Notes: All the data are annually over 1995-2005.

a. http://www.systemicpeace.org/inscr/inscr.htm

b. www.freedomhouse.org/ ratings/index.htm

c. http://web.pdx.edu/ ito/Chinn-Ito_website.htm

d. http://data.worldbank.org/indicator 
Table 2

Summary statistics

\begin{tabular}{|c|c|c|c|c|c|c|c|c|c|c|c|c|c|c|}
\hline & Mean & S.D. & Min & Q1(.25) & Median & Q3(.75) & Max & (1) & (2) & (3) & (4) & (5) & (6) & (7) \\
\hline \multicolumn{15}{|c|}{ (A) Polity measure } \\
\hline (1) $\mathrm{CO}_{2}$ & 0.23 & 1.77 & -4.48 & -1.27 & 0.48 & 1.80 & 3.18 & 1.00 & & & & & & \\
\hline (2)GDP & 8.41 & 1.29 & 5.57 & 7.27 & 8.40 & 9.50 & 10.77 & 0.93 & 1.00 & & & & & \\
\hline (3) POP & 16.24 & 1.72 & 12.65 & 15.16 & 16.17 & 17.45 & 20.99 & 0.14 & 0.05 & 1.00 & & & & \\
\hline (4)TRADE & 4.08 & 0.58 & 2.38 & 3.74 & 4.07 & 4.41 & 6.06 & 0.21 & 0.22 & -0.56 & 1.00 & & & \\
\hline (5) INDUS & 3.32 & 0.39 & 1.97 & 3.13 & 3.36 & 3.54 & 4.55 & 0.58 & 0.51 & 0.14 & 0.25 & 1.00 & & \\
\hline (6)Kaopen & 0.01 & 1.52 & -1.86 & -1.17 & -0.38 & 1.38 & 2.44 & 0.52 & 0.61 & 0.06 & 0.19 & 0.14 & 1.00 & \\
\hline (7) Polity2 & 2.80 & 6.99 & -10.00 & -5.00 & 6.00 & 9.00 & 10.00 & 0.45 & 0.51 & 0.11 & -0.002 & 0.10 & 0.39 & 1.00 \\
\hline \multicolumn{15}{|c|}{ (b) Freedom House measure } \\
\hline (1) $\mathrm{CO}_{2}$ & 0.28 & 1.70 & -4.48 & -1.03 & 0.50 & 1.75 & 3.18 & 1.00 & & & & & & \\
\hline (2) GDP & 8.48 & 1.26 & 5.57 & 7.41 & 8.62 & 9.59 & 10.77 & 0.93 & 1.00 & & & & & \\
\hline (3) POP & 15.82 & 2.10 & 11.03 & 14.74 & 16.05 & 17.27 & 20.99 & 0.04 & -0.09 & 1.00 & & & & \\
\hline (4) TRADE & 4.14 & 0.59 & 2.38 & 3.80 & 4.14 & 4.51 & 6.06 & 0.22 & 0.25 & -0.60 & 1.00 & & & \\
\hline (5) INDUS & 3.29 & 0.39 & 1.97 & 3.05 & 3.34 & 3.52 & 4.55 & 0.55 & 0.46 & 0.21 & 0.19 & 1.00 & & \\
\hline (6) Kaopen & -0.01 & 1.50 & -1.86 & -1.17 & -0.11 & 1.21 & 2.44 & 0.51 & 0.58 & 0.05 & 0.16 & 0.13 & 1.00 & \\
\hline (7) Freedom & 9.18 & 3.96 & 2.00 & 5.00 & 10.00 & 13.00 & 14.00 & 0.53 & 0.62 & -0.14 & 0.13 & 0.10 & 0.41 & 1.00 \\
\hline
\end{tabular}

All the variables are in natural log form, expect Kaopen, Polity2 and Freedom. 
Table 3

OLS regression results

\begin{tabular}{|c|c|c|c|}
\hline & pooled & OLS one-way fixed effect & OLS two-way fixed effect \\
\hline \multicolumn{4}{|c|}{ (a) Polity measure $(\mathrm{N}=2037)$} \\
\hline GDP & $1.2415 * * *(69.2511)$ & $1.0565 * * *(32.8938)$ & $1.1527 * * *(31.6530)$ \\
\hline TRADE & $0.2043^{* * *}(6.2640)$ & $-0.0205(-0.7012)$ & $0.0170(0.5620)$ \\
\hline POP & $0.1249 * * *(11.6981)$ & $-0.0607(-1.2050)$ & $0.3342 * * *(3.5145)$ \\
\hline INDUS & $0.4285^{* * *}(9.1288)$ & $0.1127 * * *(3.6417)$ & $0.0411(1.2195)$ \\
\hline Kaopen & $-0.0616^{* * *}(-5.0503)$ & $-0.0053(-0.7898)$ & $0.0014(0.1968)$ \\
\hline Polity2 & $-0.0050 * *(-2.0927)$ & $0.0039 * *(2.5448)$ & $0.0039 * *(2.4851)$ \\
\hline Constant & $-14.4858 * * *(-53.7634)$ & $-7.9756^{* * *}(-10.4990)$ & $-15.0139 * * *(-9.3355)$ \\
\hline \multicolumn{4}{|c|}{ (b) Freedom House measure $(\mathrm{N}=2037)$} \\
\hline GDP & $1.2425 * * *(71.1716)$ & $1.0671^{* * *(35.7471)}$ & $1.1045 * * *(31.2786)$ \\
\hline TRADE & $0.1901 * * *(6.2444)$ & $-0.0148(-0.5347)$ & $-0.0085(-0.3019)$ \\
\hline POP & $0.1063 * * *(12.1572)$ & $-0.0622(-1.3048)$ & $0.0389(0.4432)$ \\
\hline INDUS & $0.4137 * * *(9.5397)$ & $0.1260 * * *(4.1961)$ & $0.1032 * * *(3.1605)$ \\
\hline Kaopen & $-0.0503 * * *(-4.5269)$ & $-0.0081(-1.2621)$ & $-0.0084(-1.2643)$ \\
\hline Freedom & $-0.0094 * *(-2.2059)$ & $0.0052(1.5821)$ & $0.0056 *(1.7048)$ \\
\hline Constant & $-14.0060 * * *(-58.9673)$ & $-8.1913 * * *(-11.8953)$ & $-10.0395 * * *(-6.8941)$ \\
\hline
\end{tabular}

$\mathrm{t}$ values in parentheses. $*$ indicate statistical significance at $10 \%$; ** indicate significance at $5 \%$ and $* * *$ indicate significance at $1 \%$. 
Table 4

Quantile regression results based on Koenker (2004)

\begin{tabular}{|c|c|c|c|c|c|c|c|c|c|c|}
\hline \multicolumn{11}{|c|}{ Polity measure } \\
\hline & \multicolumn{8}{|c|}{ Quantiles } & \multirow[b]{2}{*}{ 90th } & \multirow[b]{2}{*}{95 th } \\
\hline & 10th & 20th & 30th & 40th & 50th & 60th & 70th & 80th & & \\
\hline \multirow[t]{2}{*}{ GDP } & $1.154 * * *$ & $1.170 * * *$ & $1.176^{* * *}$ & $1.173 * * *$ & $1.169 * * *$ & $1.170 * * *$ & $1.167 * * *$ & $1.153 * * *$ & $1.143^{* * *}$ & $1.139 * * *$ \\
\hline & $(27.260)$ & $(27.560)$ & $(26.581)$ & (26.359) & $(26.168)$ & $(26.069)$ & $(25.948)$ & $(24.472)$ & $(22.091)$ & $(20.485)$ \\
\hline \multirow[t]{2}{*}{ TRADE } & 0.045 & 0.052 & 0.049 & 0.058 & 0.057 & 0.060 & 0.058 & 0.062 & 0.053 & 0.040 \\
\hline & $(0.891)$ & (1.131) & $(1.121)$ & $(1.312)$ & $(1.274)$ & (1.319) & (1.233) & (1.298) & (1.091) & $(0.880)$ \\
\hline \multirow[t]{2}{*}{ POP } & $0.153 * * *$ & $0.134 * * *$ & $0.131 * * *$ & $0.131 * * *$ & $0.130 * * *$ & $0.129 * * *$ & $0.126^{* * *}$ & $0.119 * * *$ & $0.114 * * *$ & $0.108 * * *$ \\
\hline & (6.859) & $(6.857)$ & $(6.859)$ & $(6.654)$ & $(6.463)$ & (6.193) & (5.885) & $(5.566)$ & (5.003) & $(4.668)$ \\
\hline \multirow[t]{2}{*}{ INDUS } & 0.071 & 0.132 & $0.143^{*}$ & $0.138^{*}$ & $0.152 * *$ & $0.148 * *$ & $0.150 * *$ & $0.168 * *$ & $0.182 * *$ & $0.206^{* *}$ \\
\hline & $(0.838)$ & (1.584) & (1.874) & (1.915) & $(2.208)$ & $(2.170)$ & $(2.245)$ & (2.439) & $(2.360)$ & $(2.429)$ \\
\hline \multirow[t]{2}{*}{ Kaopen } & 0.023 & 0.005 & -0.001 & -0.001 & -0.003 & -0.005 & -0.006 & -0.001 & 0.001 & 0.002 \\
\hline & $(1.412)$ & $(0.369)$ & $(-0.110)$ & $(-0.113)$ & $(-0.283)$ & $(-0.395)$ & $(-0.467)$ & $(-0.092)$ & $(0.096)$ & $(0.117)$ \\
\hline \multirow[t]{2}{*}{ Polity2 } & $0.017 * * *$ & $0.010 * * *$ & $0.007 * * *$ & $0.005 * * *$ & $0.004 * *$ & 0.003 & 0.002 & 0.001 & -0.003 & $-0.011 * *$ \\
\hline & $(3.879)$ & $(3.100)$ & $(2.715)$ & $(2.738)$ & $(2.257)$ & $(1.542)$ & $(0.847)$ & $(0.235)$ & $(-0.890)$ & $(-2.034)$ \\
\hline \multirow[t]{2}{*}{ Constant } & $-12.662 * * *$ & $-12.631 * * *$ & $-12.587 * * *$ & $-12.526^{* * *}$ & $-12.443 * * *$ & $-12.402 * * *$ & $-12.254 * * *$ & $-11.987 * * *$ & $-11.737 * * *$ & $-11.535 * * *$ \\
\hline & $(-23.064)$ & $(-24.791)$ & $(-25.714)$ & $(-26.544)$ & $(-27.844)$ & $(-28.226)$ & $(-28.022)$ & $(-28.089)$ & $(-26.720)$ & $(-25.784)$ \\
\hline \multicolumn{11}{|l|}{ Panel (B) } \\
\hline \multicolumn{11}{|l|}{ Freedom } \\
\hline \multicolumn{11}{|c|}{ House measure } \\
\hline \multirow[t]{2}{*}{ GDP } & $1.155^{* * *}$ & $1.168 * * *$ & $1.172 * * *$ & $1.175^{* * *}$ & $1.175 * * *$ & $1.175^{* * *}$ & $1.174 * * *$ & $1.169 * * *$ & $1.177 * * *$ & $1.182 * * *$ \\
\hline & $(25.111)$ & $(27.870)$ & $(27.706)$ & $(27.683)$ & $(28.050)$ & $(27.639)$ & $(27.536)$ & $(27.165)$ & $(24.358)$ & $(22.856)$ \\
\hline \multirow[t]{2}{*}{ TRADE } & 0.038 & 0.032 & 0.030 & 0.033 & 0.041 & 0.036 & 0.042 & 0.043 & 0.033 & 0.016 \\
\hline & $(0.632)$ & $(0.625)$ & $(0.618)$ & $(0.700)$ & $(0.857)$ & $(0.726)$ & $(0.831)$ & $(0.832)$ & $(0.635)$ & $(0.309)$ \\
\hline \multirow[t]{2}{*}{ POP } & $0.120 * * *$ & $0.099 * * *$ & $0.093 * * *$ & $0.090 * * *$ & $0.091 * * *$ & $0.087 * * *$ & $0.082 * * *$ & $0.076 * * *$ & $0.069 * * *$ & $0.059 * * *$ \\
\hline & $(6.803)$ & $(7.134)$ & $(8.011)$ & $(8.445)$ & $(8.637)$ & $(8.163)$ & (7.635) & $(6.884)$ & $(5.795)$ & $(4.327)$ \\
\hline \multirow[t]{2}{*}{ INDUS } & 0.113 & $0.192 * *$ & $0.190 * *$ & $0.184 * *$ & $0.181 * *$ & $0.186^{* *}$ & $0.182 * * *$ & $0.201 * * *$ & $0.190 * *$ & $0.211^{* * *}$ \\
\hline & (1.172) & $(2.111)$ & $(2.252)$ & $(2.338)$ & $(2.445)$ & (2.609) & $(2.689)$ & $(2.818)$ & $(2.463)$ & $(2.648)$ \\
\hline \multirow[t]{2}{*}{ Kaopen } & 0.011 & 0.002 & -0.002 & -0.005 & -0.007 & -0.009 & -0.011 & -0.009 & -0.009 & -0.008 \\
\hline & $(0.642)$ & $(0.179)$ & $(-0.148)$ & $(-0.440)$ & $(-0.584)$ & $(-0.754)$ & $(-0.885)$ & $(-0.661)$ & $(-0.567)$ & $(-0.432)$ \\
\hline \multirow[t]{2}{*}{ Freedom } & $0.028 * * *$ & $0.014 * *$ & $0.010^{*}$ & 0.007 & 0.005 & 0.004 & 0.002 & -0.002 & -0.013 & $-0.024 * *$ \\
\hline & $(3.287)$ & $(2.196)$ & $(1.942)$ & (1.559) & (1.089) & $(0.879)$ & $(0.289)$ & $(-0.345)$ & $(-1.456)$ & $(-2.446)$ \\
\hline \multirow[t]{2}{*}{ Constant } & $-12.483 * * *$ & $-12.265 * * *$ & $-12.090 * * *$ & $-11.978 * * *$ & $-11.918 * * *$ & $-11.818 * * *$ & $-11.647 * * *$ & $-11.460 * * *$ & $-11.128 * * *$ & $-10.840 * * *$ \\
\hline & $(-20.982)$ & $(-24.087)$ & $(-25.337)$ & $(-26.733)$ & $(-27.372)$ & $(-27.729)$ & $(-27.642)$ & $(-26.537)$ & $(-25.245)$ & $(-23.408)$ \\
\hline
\end{tabular}

$\mathrm{t}$ values in parentheses. $*$ indicate statistical significance at $10 \%$; * indicate significance at $5 \%$ and $* * *$ indicate significance at $1 \%$. 
Table 5

Robustness analysis: alternative estimation technique based on Canay (2011)

Panel (A)

Polity measure

\begin{tabular}{|c|c|c|c|c|c|c|c|c|c|c|}
\hline & \multicolumn{8}{|c|}{ Quantiles } & \multirow[b]{2}{*}{ 90th } & \multirow[b]{2}{*}{ 95th } \\
\hline & 10th & 20th & 30th & 40th & 50th & 60th & 70th & 80th & & \\
\hline \multirow[t]{2}{*}{ GDP } & $1.158 * * *$ & $1.161 * * *$ & $1.155 * * *$ & $1.151 * * *$ & $1.148 * * *$ & $1.146^{* * *}$ & $1.145 * * *$ & $1.135^{* * *}$ & $1.129 * * *$ & $1.125 * * *$ \\
\hline & (66.034) & (60.399) & $(73.814)$ & $(81.499)$ & $(80.815)$ & $(72.968)$ & $(71.572)$ & $(70.863)$ & $(70.216)$ & $(51.819)$ \\
\hline \multirow[t]{2}{*}{ TRADE } & 0.016 & 0.026 & 0.016 & 0.020 & 0.022 & 0.026 & 0.022 & 0.026 & 0.046 & 0.032 \\
\hline & $(0.673)$ & $(0.943)$ & $(0.512)$ & $(0.703)$ & $(0.870)$ & $(0.970)$ & (0.889) & $(0.798)$ & (1.506) & $(0.972)$ \\
\hline \multirow[t]{2}{*}{ POP } & $0.352 * * *$ & $0.343 * * *$ & $0.335 * * *$ & $0.336 * * *$ & $0.333 * * *$ & $0.334 * * *$ & $0.330 * * *$ & $0.322 * * *$ & $0.323 * * *$ & $0.311 * * *$ \\
\hline & $(33.646)$ & (33.142) & $(35.655)$ & $(36.738)$ & $(35.654)$ & $(39.591)$ & $(32.472)$ & $(33.120)$ & $(30.495)$ & $(24.103)$ \\
\hline \multirow[t]{2}{*}{ INDUS } & -0.020 & 0.017 & 0.042 & 0.044 & 0.058 & 0.056 & 0.063 & $0.094^{*}$ & 0.095 & $0.092 *$ \\
\hline & $(-0.368)$ & $(0.355)$ & $(1.024)$ & $(1.283)$ & $(1.282)$ & $(1.423)$ & (1.529) & (1.769) & (1.569) & (1.742) \\
\hline \multirow[t]{2}{*}{ Kaopen } & 0.006 & 0.002 & 0.004 & 0.004 & -0.00001 & 0.0003 & 0.0004 & 0.002 & 0.005 & 0.006 \\
\hline & $(0.590)$ & $(0.173)$ & $(0.415)$ & $(0.385)$ & $(-0.001)$ & $(0.027)$ & $(0.039)$ & $(0.189)$ & $(0.474)$ & $(0.393)$ \\
\hline \multirow[t]{2}{*}{ Polity2 } & $0.015^{* * *}$ & $0.009 * * *$ & $0.006^{* * *}$ & $0.005^{* * *}$ & $0.005^{* *}$ & $0.004 *$ & 0.002 & 0.0008 & $-0.007 * *$ & $-0.012 * * *$ \\
\hline & $(4.324)$ & (3.213) & $(2.774)$ & $(2.626)$ & $(2.272)$ & $(1.9052)$ & (1.028) & $(0.293)$ & $(-2.108)$ & $(-2.354)$ \\
\hline \multirow[t]{2}{*}{ Constant } & $-15.399 * * *$ & $-15.368 * * *$ & $-15.132 * * *$ & $-15.116 * * *$ & $-15.061 * * *$ & $-14.994 * * *$ & $-14.882 * * *$ & $-14.678 * * *$ & $-14.596 * * *$ & $-14.213 * * *$ \\
\hline & $(-26.883)$ & $(-31.917)$ & $(-40.361)$ & $(-38.857)$ & $(-44.572)$ & $(-45.878)$ & $(-32.250)$ & $(-34.627)$ & $(-37.475)$ & $(-32.620)$ \\
\hline
\end{tabular}

Panel (B)

Freedom

House measure

\begin{tabular}{|c|c|c|c|c|c|c|c|c|c|c|}
\hline GDP & $\begin{array}{l}1.087 * * * \\
(61.774)\end{array}$ & $\begin{array}{l}1.099 * * * \\
(54.865)\end{array}$ & $\begin{array}{l}1.099 * * * \\
(68.518)\end{array}$ & $\begin{array}{l}1.100 * * * \\
(62.359)\end{array}$ & $\begin{array}{l}1.103 * * * \\
(61.145)\end{array}$ & $\begin{array}{l}1.101 * * * \\
(66.669)\end{array}$ & $\begin{array}{l}1.100 * * * \\
(55.404)\end{array}$ & $\begin{array}{l}1.096^{* * *} \\
(51.826)\end{array}$ & $\begin{array}{l}1.109 * * * \\
(61.110)\end{array}$ & $\begin{array}{l}1.119 * * * \\
(46.392)\end{array}$ \\
\hline TRADE & $\begin{array}{l}-0.003 \\
(-0.095)\end{array}$ & $\begin{array}{l}-0.006 \\
(-0.196)\end{array}$ & $\begin{array}{l}-0.010 \\
(-0.341)\end{array}$ & $\begin{array}{l}-0.003 \\
(-0.106)\end{array}$ & $\begin{array}{l}-0.003 \\
(-0.1)\end{array}$ & $\begin{array}{l}-0.0009 \\
(-0.032)\end{array}$ & $\begin{array}{l}0.005 \\
(0.168)\end{array}$ & $\begin{array}{l}0.002 \\
(0.054)\end{array}$ & $\begin{array}{l}0.011 \\
(0.375)\end{array}$ & $\begin{array}{l}0.010 \\
(0.301)\end{array}$ \\
\hline POP & $\begin{array}{l}0.067 * * * \\
(5.371)\end{array}$ & $\begin{array}{l}0.051^{* * *} \\
(5.473)\end{array}$ & $\begin{array}{l}0.042 * * * \\
(4.892)\end{array}$ & $\begin{array}{l}0.041^{* * *} \\
(4.644)\end{array}$ & $\begin{array}{l}0.038^{* * *} \\
(4.219)\end{array}$ & $\begin{array}{l}0.035^{* * *} \\
(4.611)\end{array}$ & $\begin{array}{l}0.032 * * * \\
(3.999)\end{array}$ & $\begin{array}{l}0.024 * * * \\
(2.492)\end{array}$ & $\begin{array}{l}0.019 * \\
(1.931)\end{array}$ & $\begin{array}{l}0.012 \\
(1.143)\end{array}$ \\
\hline INDUS & $\begin{array}{l}0.078 \\
(1.478)\end{array}$ & $\begin{array}{l}0.106^{* *} \\
(2.042)\end{array}$ & $\begin{array}{l}0.112 * * \\
(2.243)\end{array}$ & $\begin{array}{l}0.115^{* * *} \\
(2.806)\end{array}$ & $\begin{array}{l}0.106^{* *} \\
(2.199)\end{array}$ & $\begin{array}{l}0.113 * * * \\
(2.778)\end{array}$ & $\begin{array}{l}0.123 * * \\
(2.546)\end{array}$ & $\begin{array}{l}0.141 * * * \\
(2.767)\end{array}$ & $\begin{array}{l}0.132 * * * \\
(2.764)\end{array}$ & $\begin{array}{l}0.129 * * \\
(2.015)\end{array}$ \\
\hline Kaopen & $\begin{array}{l}0.002 \\
(0.223)\end{array}$ & $\begin{array}{l}-0.004 \\
(-0.289)\end{array}$ & $\begin{array}{l}-0.003 \\
(-0.301)\end{array}$ & $\begin{array}{l}-0.006 \\
(-0.599)\end{array}$ & $\begin{array}{l}-0.009 \\
(-0.846)\end{array}$ & $\begin{array}{l}-0.009 \\
(-0.911)\end{array}$ & $\begin{array}{l}-0.013 \\
(-1.096)\end{array}$ & $\begin{array}{l}-0.011 \\
(-0.898)\end{array}$ & $\begin{array}{l}-0.008 \\
(-0.807)\end{array}$ & $\begin{array}{l}-0.010 \\
(-0.677)\end{array}$ \\
\hline Freedom & $\begin{array}{l}0.025^{* * *} \\
(3.760)\end{array}$ & $\begin{array}{l}0.015^{* * *} \\
(2.936)\end{array}$ & $\begin{array}{l}0.009 * * \\
(2.235)\end{array}$ & $\begin{array}{l}0.007 * \\
(1.814)\end{array}$ & $\begin{array}{l}0.006 \\
(1.245)\end{array}$ & $\begin{array}{l}0.004 \\
(0.935)\end{array}$ & $\begin{array}{l}0.003 \\
(0.699)\end{array}$ & $\begin{array}{l}-0.001 \\
(-0.166)\end{array}$ & $\begin{array}{l}-0.017 * * \\
(-2.362)\end{array}$ & $\begin{array}{l}-0.029 * * * \\
(-3.236)\end{array}$ \\
\hline Constant & $\begin{array}{l}-10.695^{* * *} \\
(-23.020)\end{array}$ & $\begin{array}{l}-10.488^{* * *} \\
(-25.315)\end{array}$ & $\begin{array}{l}-10.195 * * * \\
(-22.489)\end{array}$ & $\begin{array}{l}-10.164 * * * \\
(-26.900)\end{array}$ & $\begin{array}{l}-10.006^{* * *} \\
(-28.013)\end{array}$ & $\begin{array}{l}-9.979 * * * \\
(-27.365)\end{array}$ & $\begin{array}{l}-9.889 * * * \\
(-25.818)\end{array}$ & $\begin{array}{l}-9.633^{* * *} \\
(-16.445)\end{array}$ & $\begin{array}{l}-9.391 * * * \\
(-21.268)\end{array}$ & $\begin{array}{l}-9.190 * * * \\
(-17.615)\end{array}$ \\
\hline
\end{tabular}

$\mathrm{t}$ values in parentheses. $*$ indicate statistical significance at $10 \%$; * indicate significance at $5 \%$ and $* * *$ indicate significance at $1 \%$. 
Table 6

Robustness analysis: Nonlinear relationship between income and $\mathrm{CO}_{2}$ emissions

Panel (A)

Polity measure



t values in parentheses. ${ }^{*}$ indicate statistical significance at $10 \%$; * indicate significance at $5 \%$ and $* * *$ indicate significance at $1 \%$. 
Table 7

Robustness analysis: alternative values of $\lambda$ (Polity measure)

\begin{tabular}{|c|c|c|c|c|c|c|c|c|c|c|c|}
\hline \multirow[t]{2}{*}{ Panel (A) } & & \multicolumn{10}{|c|}{ Quantile } \\
\hline & & 0.1 & 0.2 & 0.3 & 0.4 & 0.5 & 0.6 & 0.7 & 0.8 & 0.9 & 0.95 \\
\hline \multirow{2}{*}{$\lambda=0.1$} & Polity2 & $\begin{array}{l}0.016^{* * *} \\
(3.490)\end{array}$ & $\begin{array}{l}0.009 * * * \\
(2.896)\end{array}$ & $\begin{array}{l}0.007 * * * \\
(2.728)\end{array}$ & $\begin{array}{l}0.005^{* *} \\
(2.436)\end{array}$ & $\begin{array}{l}0.005^{* *} \\
(2.411)\end{array}$ & $\begin{array}{l}0.003 \\
(1.631)\end{array}$ & $\begin{array}{l}0.002 \\
(1.041)\end{array}$ & $\begin{array}{l}0.002 \\
(0.704)\end{array}$ & $\begin{array}{l}-0.002 \\
(-0.690)\end{array}$ & $\begin{array}{l}-0.009 * \\
(-1.934)\end{array}$ \\
\hline & Kaopen & $\begin{array}{l}0.017 \\
(1.118)\end{array}$ & $\begin{array}{l}0.001 \\
(0.099)\end{array}$ & $\begin{array}{l}0.003 \\
(0.304)\end{array}$ & $\begin{array}{l}0.004 \\
(0.386)\end{array}$ & $\begin{array}{l}0.0003 \\
(0.030)\end{array}$ & $\begin{array}{l}-0.001 \\
(-0.127)\end{array}$ & $\begin{array}{l}-0.003 \\
(-0.230)\end{array}$ & $\begin{array}{l}-0.001 \\
(-0.043)\end{array}$ & $\begin{array}{l}0.005 \\
(0.279)\end{array}$ & $\begin{array}{l}0.002 \\
(0.147)\end{array}$ \\
\hline \multirow{2}{*}{$\lambda=0.3$} & Polity2 & $\begin{array}{l}0.016^{* * *} \\
(3.569)\end{array}$ & $\begin{array}{l}0.009 * * * \\
(2.751)\end{array}$ & $\begin{array}{l}0.006^{* *} \\
(2.409)\end{array}$ & $\begin{array}{l}0.005^{* *} \\
(2.324)\end{array}$ & $\begin{array}{l}0.004 * * \\
(1.998)\end{array}$ & $\begin{array}{l}0.003 \\
(1.445)\end{array}$ & $\begin{array}{l}0.002 \\
(0.870)\end{array}$ & $\begin{array}{l}0.001 \\
(0.463)\end{array}$ & $\begin{array}{l}-0.002 \\
(-0.582)\end{array}$ & $\begin{array}{l}-0.009 * \\
(-1.690)\end{array}$ \\
\hline & Kaopen & $\begin{array}{l}0.020 \\
(1.217)\end{array}$ & $\begin{array}{l}0.001 \\
(0.052)\end{array}$ & $\begin{array}{l}0.002 \\
(0.173)\end{array}$ & $\begin{array}{l}0.002 \\
(0.193)\end{array}$ & $\begin{array}{l}-0.001 \\
(-0.113)\end{array}$ & $\begin{array}{l}-0.002 \\
(-0.201)\end{array}$ & $\begin{array}{l}-0.003 \\
(-0.269)\end{array}$ & $\begin{array}{l}-0.001 \\
(-0.072)\end{array}$ & $\begin{array}{l}0.003 \\
(0.210)\end{array}$ & $\begin{array}{l}0.005 \\
(0.319)\end{array}$ \\
\hline \multirow{2}{*}{$\lambda=0.5$} & Polity2 & $\begin{array}{l}0.015 * * * \\
(3.845)\end{array}$ & $\begin{array}{l}0.009 * * * \\
(2.958)\end{array}$ & $\begin{array}{l}0.006^{* *} \\
(2.437)\end{array}$ & $\begin{array}{l}0.005^{* *} \\
(2.499)\end{array}$ & $\begin{array}{l}0.004 * * \\
(2.186)\end{array}$ & $\begin{array}{l}0.003 \\
(1.648)\end{array}$ & $\begin{array}{l}0.002 \\
(1.022)\end{array}$ & $\begin{array}{l}0.001 \\
(0.357)\end{array}$ & $\begin{array}{l}-0.002 \\
(-0.693)\end{array}$ & $\begin{array}{l}-0.009 * \\
(-1.705)\end{array}$ \\
\hline & Kaopen & $\begin{array}{l}0.021 \\
(1.301)\end{array}$ & $\begin{array}{l}0.001 \\
(0.074)\end{array}$ & $\begin{array}{l}0.002 \\
(0.148)\end{array}$ & $\begin{array}{l}0.001 \\
(0.073)\end{array}$ & $\begin{array}{l}-0.002 \\
(-0.194)\end{array}$ & $\begin{array}{l}-0.003 \\
(-0.263)\end{array}$ & $\begin{array}{l}-0.004 \\
(-0.296)\end{array}$ & $\begin{array}{l}-0.003 \\
(-0.215)\end{array}$ & $\begin{array}{l}0.002 \\
(0.153)\end{array}$ & $\begin{array}{l}0.001 \\
(0.093)\end{array}$ \\
\hline \multirow{2}{*}{$\lambda=0.7$} & Polity2 & $\begin{array}{l}0.016^{* * *} \\
(3.947)\end{array}$ & $\begin{array}{l}0.009^{* * *} \\
(2.881)\end{array}$ & $\begin{array}{l}0.006^{* *} \\
(2.484)\end{array}$ & $\begin{array}{l}0.005^{* * *} \\
(2.585)\end{array}$ & $\begin{array}{l}0.004 * * \\
(2.157)\end{array}$ & $\begin{array}{l}0.003 \\
(1.645)\end{array}$ & $\begin{array}{l}0.002 \\
(0.973)\end{array}$ & $\begin{array}{l}0.001 \\
(0.338)\end{array}$ & $\begin{array}{l}-0.003 \\
(-0.813)\end{array}$ & $\begin{array}{l}-0.009 * \\
(-1.788)\end{array}$ \\
\hline & Kaopen & $\begin{array}{l}0.023 \\
(1.431)\end{array}$ & $\begin{array}{l}0.002 \\
(0.195)\end{array}$ & $\begin{array}{l}0.0003 \\
(0.024)\end{array}$ & $\begin{array}{l}-0.0003 \\
(-0.029)\end{array}$ & $\begin{array}{l}-0.003 \\
(-0.297)\end{array}$ & $\begin{array}{l}-0.004 \\
(-0.369)\end{array}$ & $\begin{array}{l}-0.004 \\
(-0.368)\end{array}$ & $\begin{array}{l}-0.001 \\
(-0.102)\end{array}$ & $\begin{array}{l}0.002 \\
(0.127)\end{array}$ & $\begin{array}{l}0.001 \\
(0.072)\end{array}$ \\
\hline \multirow{2}{*}{$\lambda=0.9$} & Polity2 & $\begin{array}{l}0.017 * * * \\
(4.023)\end{array}$ & $\begin{array}{l}0.010 * * * \\
(2.932)\end{array}$ & $\begin{array}{l}0.006^{* *} \\
(2.383)\end{array}$ & $\begin{array}{l}0.005^{* *} \\
(2.437)\end{array}$ & $\begin{array}{l}0.004 * * \\
(2.097)\end{array}$ & $\begin{array}{l}0.003 \\
(1.475)\end{array}$ & $\begin{array}{l}0.002 \\
(0.809)\end{array}$ & $\begin{array}{l}0.001 \\
(0.265)\end{array}$ & $\begin{array}{l}-0.003 \\
(-0.878)\end{array}$ & $\begin{array}{l}-0.010^{* *} \\
(-2.018)\end{array}$ \\
\hline & Kaopen & $\begin{array}{l}0.023 \\
(1.565)\end{array}$ & $\begin{array}{l}0.004 \\
(0.336)\end{array}$ & $\begin{array}{l}-0.001 \\
(-0.088)\end{array}$ & $\begin{array}{l}-0.001 \\
(-0.115)\end{array}$ & $\begin{array}{l}-0.003 \\
(-0.255)\end{array}$ & $\begin{array}{l}-0.004 \\
(-0.391)\end{array}$ & $\begin{array}{l}-0.006 \\
(-0.461)\end{array}$ & $\begin{array}{l}-0.001 \\
(-0.059)\end{array}$ & $\begin{array}{l}0.003 \\
(0.176)\end{array}$ & $\begin{array}{l}0.001 \\
(0.067)\end{array}$ \\
\hline \multirow{2}{*}{$\lambda=1.1$} & Polity2 & $\begin{array}{l}0.017 * * * \\
(3.785)\end{array}$ & $\begin{array}{l}0.010 * * * \\
(3.143)\end{array}$ & $\begin{array}{l}0.006 * * * \\
(2.567)\end{array}$ & $\begin{array}{l}0.005 * * * \\
(2.591)\end{array}$ & $\begin{array}{l}0.004 * * \\
(2.220)\end{array}$ & $\begin{array}{l}0.003 \\
(1.573)\end{array}$ & $\begin{array}{l}0.002 \\
(0.783)\end{array}$ & $\begin{array}{l}0.0004 \\
(0.180)\end{array}$ & $\begin{array}{l}-0.003 \\
(-1.123)\end{array}$ & $\begin{array}{l}-0.011 * * \\
(-2.139)\end{array}$ \\
\hline & Kaopen & $\begin{array}{l}0.023 \\
(1.448)\end{array}$ & $\begin{array}{l}0.005 \\
(0.478)\end{array}$ & $\begin{array}{l}-0.002 \\
(-0.148)\end{array}$ & $\begin{array}{l}-0.002 \\
(-0.205)\end{array}$ & $\begin{array}{l}-0.003 \\
(-0.309)\end{array}$ & $\begin{array}{l}-0.004 \\
(-0.393)\end{array}$ & $\begin{array}{l}-0.005 \\
(-0.471)\end{array}$ & $\begin{array}{l}-0.002 \\
(-0.118)\end{array}$ & $\begin{array}{l}0.001 \\
(0.085)\end{array}$ & $\begin{array}{l}0.004 \\
(0.235)\end{array}$ \\
\hline \multirow{2}{*}{$\lambda=1.3$} & Polity2 & $\begin{array}{l}0.017 * * * \\
(3.897)\end{array}$ & $\begin{array}{l}0.010^{* * *} \\
(3.237)\end{array}$ & $\begin{array}{l}0.006^{* *} \\
(2.548)\end{array}$ & $\begin{array}{l}0.005 * * \\
(2.461)\end{array}$ & $\begin{array}{l}0.004 \\
(1.950)\end{array}$ & $\begin{array}{l}0.003 \\
(1.387)\end{array}$ & $\begin{array}{l}0.001 \\
(0.672)\end{array}$ & $\begin{array}{l}0.0003 \\
(0.129)\end{array}$ & $\begin{array}{l}-0.003 \\
(-0.943)\end{array}$ & $\begin{array}{l}-0.011 * * \\
(-2.251)\end{array}$ \\
\hline & Kaopen & $\begin{array}{l}0.023 \\
(1.222)\end{array}$ & $\begin{array}{l}0.006 \\
(0.432)\end{array}$ & $\begin{array}{l}-0.002 \\
(-0.155)\end{array}$ & $\begin{array}{l}-0.002 \\
(-0.131)\end{array}$ & $\begin{array}{l}-0.003 \\
(-0.306)\end{array}$ & $\begin{array}{l}-0.004 \\
(-0.314)\end{array}$ & $\begin{array}{l}-0.006 \\
(-0.451)\end{array}$ & $\begin{array}{l}-0.001 \\
(-0.080)\end{array}$ & $\begin{array}{l}0.0001 \\
(0.007)\end{array}$ & $\begin{array}{l}0.003 \\
(0.195)\end{array}$ \\
\hline \multirow{2}{*}{$\lambda=1.5$} & Polity2 & $\begin{array}{l}0.017 * * * \\
(3.922)\end{array}$ & $\begin{array}{l}0.010 * * * \\
(3.076)\end{array}$ & $\begin{array}{l}0.007 * * * \\
(2.695)\end{array}$ & $\begin{array}{l}0.005^{* *} \\
(2.443)\end{array}$ & $\begin{array}{l}0.004 \\
(1.936)\end{array}$ & $\begin{array}{l}0.003 \\
(1.404)\end{array}$ & $\begin{array}{l}0.001 \\
(0.594)\end{array}$ & $\begin{array}{l}0.0003 \\
(0.137)\end{array}$ & $\begin{array}{l}-0.003 \\
(-0.970)\end{array}$ & $\begin{array}{l}-0.011 * * \\
(-2.348)\end{array}$ \\
\hline & Kaopen & $\begin{array}{l}0.023 \\
(1.200)\end{array}$ & $\begin{array}{l}0.005 \\
(0.354)\end{array}$ & $\begin{array}{l}-0.001 \\
(-0.118)\end{array}$ & $\begin{array}{l}-0.002 \\
(-0.190)\end{array}$ & $\begin{array}{l}-0.003 \\
(-0.275)\end{array}$ & $\begin{array}{l}-0.003 \\
(-0.251)\end{array}$ & $\begin{array}{l}-0.006 \\
(-0.471)\end{array}$ & $\begin{array}{l}-0.0004 \\
(-0.027)\end{array}$ & $\begin{array}{l}-0.001 \\
(-0.047)\end{array}$ & $\begin{array}{l}0.003 \\
(0.160)\end{array}$ \\
\hline
\end{tabular}

t values in parentheses. ${ }^{*}$ indicate statistical significance at $10 \%$; * indicate significance at $5 \%$ and $* * *$ indicate significance at $1 \%$. 
Table 8

Robustness analysis: alternative values of $\lambda$ (Freedom House measure)

\begin{tabular}{|c|c|c|c|c|c|c|c|c|c|c|c|}
\hline \multirow{2}{*}{$\begin{array}{l}\text { Panel } \\
\text { (B) }\end{array}$} & & \multicolumn{10}{|c|}{ Quantile } \\
\hline & & 0.1 & 0.2 & 0.3 & 0.4 & 0.5 & 0.6 & 0.7 & 0.8 & 0.9 & 0.95 \\
\hline \multirow{4}{*}{$\lambda=0.1$} & & $0.026^{* * *}$ & $0.016 * *$ & $0.011 * *$ & 0.007 & 0.006 & 0.005 & 0.004 & 0.0005 & -0.010 & $-0.020 *$ \\
\hline & & $(3.409)$ & $(2.470)$ & (1.966) & (1.491) & $(1.258)$ & $(0.874)$ & $(0.614)$ & $(0.070)$ & $(-1.004)$ & $(-1.853)$ \\
\hline & & 0.005 & -0.003 & -0.002 & -0.003 & -0.008 & -0.010 & -0.013 & -0.013 & -0.013 & -0.010 \\
\hline & & $(0.318)$ & $(-0.230)$ & $(-0.163)$ & $(-0.280)$ & $(-0.716)$ & $(-0.887)$ & $(-1.120)$ & $(-0.991)$ & $(-0.847)$ & $(-0.611)$ \\
\hline \multirow{4}{*}{$\lambda=0.3$} & & $0.027 * * *$ & $0.015 * *$ & $0.011 * *$ & 0.008 & 0.006 & 0.005 & 0.003 & 0.001 & -0.010 & $-0.019 *$ \\
\hline & & $(3.285)$ & $(2.316)$ & (2.077) & (1.679) & (1.167) & $(0.927)$ & $(0.553)$ & $(0.089)$ & $(-1.077)$ & $(-1.862)$ \\
\hline & & 0.006 & -0.001 & 0.00002 & -0.002 & -0.007 & -0.010 & -0.012 & -0.012 & -0.012 & -0.012 \\
\hline & & $(0.343)$ & $(-0.094)$ & $(0.002)$ & $(-0.217)$ & $(-0.704)$ & $(-1.000)$ & $(-1.149)$ & $(-1.011)$ & $(-0.844)$ & $(-0.807)$ \\
\hline \multirow{4}{*}{$\lambda=0.5$} & & $0.027 * * *$ & $0.015 * *$ & $0.011 * *$ & 0.008 & 0.005 & 0.005 & 0.003 & -0.0001 & -0.009 & $-0.021 *$ \\
\hline & & (3.338) & $(2.380)$ & $(2.145)$ & $(1.625)$ & $(1.080)$ & $(0.948)$ & $(0.500)$ & $(-0.013)$ & $(-0.971)$ & $(-1.952)$ \\
\hline & & 0.009 & -0.0002 & 0.0003 & -0.003 & -0.006 & -0.010 & -0.011 & -0.011 & -0.009 & -0.008 \\
\hline & & $(0.596)$ & $(-0.018)$ & $(0.031)$ & $(-0.281)$ & $(-0.600)$ & $(-0.912)$ & $(-1.020)$ & $(-0.852)$ & $(-0.644)$ & $(-0.528)$ \\
\hline \multirow{4}{*}{$\lambda=0.7$} & & $0.027 * * *$ & $0.014 * *$ & $0.010 * *$ & $0.008^{*}$ & 0.005 & 0.004 & 0.002 & -0.002 & -0.011 & $-0.022 * *$ \\
\hline & & (3.118) & $(2.262)$ & $(2.135)$ & $(1.771)$ & (1.177) & $(0.924)$ & $(0.327)$ & $(-0.252)$ & $(-1.181)$ & $(-2.235)$ \\
\hline & & 0.010 & -0.0005 & -0.001 & -0.004 & -0.007 & -0.010 & -0.013 & -0.011 & -0.009 & -0.007 \\
\hline & & $(0.565)$ & $(-0.047)$ & $(-0.112)$ & $(-0.346)$ & $(-0.639)$ & $(-0.905)$ & $(-1.101)$ & $(-0.831)$ & $(-0.614)$ & $(-0.409)$ \\
\hline \multirow{4}{*}{$\lambda=0.9$} & & $0.028 * * *$ & $0.015 * *$ & $0.010^{*}$ & 0.008 & 0.005 & 0.005 & 0.002 & -0.002 & -0.013 & $-0.024 * *$ \\
\hline & & $(3.531)$ & $(2.196)$ & $(1.823)$ & (1.518) & (1.073) & $(0.895)$ & $(0.296)$ & $(-0.227)$ & $(-1.460)$ & $(-2.337)$ \\
\hline & & 0.010 & 0.002 & -0.002 & -0.004 & -0.007 & -0.009 & -0.012 & -0.010 & -0.009 & -0.009 \\
\hline & & $(0.568)$ & $(0.145)$ & $(-0.161)$ & $(-0.377)$ & $(-0.657)$ & $(-0.863)$ & $(-1.075)$ & $(-0.777)$ & $(-0.561)$ & $(-0.526)$ \\
\hline \multirow{4}{*}{$\lambda=1.1$} & & $0.027 * * *$ & $0.014 * *$ & $0.010^{*}$ & 0.007 & 0.005 & 0.004 & 0.001 & -0.003 & -0.013 & $-0.025 * * *$ \\
\hline & & $(3.286)$ & $(2.285)$ & $(1.885)$ & (1.519) & $(0.990)$ & $(0.773)$ & $(0.238)$ & $(-0.415)$ & $(-1.401)$ & $(-2.735)$ \\
\hline & & 0.010 & 0.003 & -0.002 & -0.005 & -0.006 & -0.009 & -0.011 & -0.009 & -0.008 & -0.009 \\
\hline & 110 & $(0.542)$ & $(0.234)$ & $(-0.158)$ & $(-0.481)$ & $(-0.537)$ & $(-0.783)$ & $(-0.911)$ & $(-0.6920$ & $(-0.510)$ & $(-0.552)$ \\
\hline \multirow{4}{*}{$\lambda=1.3$} & & $0.027 * * *$ & $0.014 * *$ & 0.009 & 0.007 & 0.005 & 0.003 & 0.0008 & -0.003 & -0.014 & $-0.026 * * *$ \\
\hline & OIII & $(3.048)$ & $(2.103)$ & (1.666) & (1.357) & (0.994) & $(0.667)$ & $(0.155)$ & $(-0.493)$ & $(-1.596)$ & $(-2.839)$ \\
\hline & & 0.012 & 0.003 & -0.001 & -0.005 & -0.006 & -0.008 & -0.011 & -0.009 & -0.008 & -0.007 \\
\hline & 11 & $(0.663)$ & $(0.219)$ & $(-0.134)$ & $(-0.452)$ & $(-0.585)$ & $(-0.771)$ & $(-0.897)$ & $(-0.695)$ & $(-0.486)$ & $(-0.420)$ \\
\hline \multirow{4}{*}{$\lambda=1.5$} & & $0.027 * * *$ & $0.014 * *$ & 0.008 & 0.006 & 0.004 & 0.003 & 0.001 & -0.004 & -0.014 & $-0.026 * * *$ \\
\hline & & $(3.286)$ & $(2.091)$ & $(1.545)$ & $(1.265)$ & $(0.900)$ & $(0.600)$ & $(0.098)$ & $(-0.592)$ & $(-1.510)$ & $(-2.938)$ \\
\hline & & 0.014 & 0.001 & -0.001 & -0.005 & -0.006 & -0.009 & -0.011 & -0.009 & -0.008 & -0.010 \\
\hline & & $(0.739)$ & $(0.101)$ & $(-0.119)$ & $(-0.458)$ & $(-0.573)$ & $(-0.823)$ & $(-0.977)$ & $(-0.847)$ & $(-0.601)$ & $(-0.695)$ \\
\hline
\end{tabular}

$\mathrm{t}$ values in parentheses. ${ }^{*}$ indicate statistical significance at $10 \%$; ** indicate significance at $5 \%$ and $* * *$ indicate significance at $1 \%$. 
Table 9

Robustness alayisis: exclude Kaopen

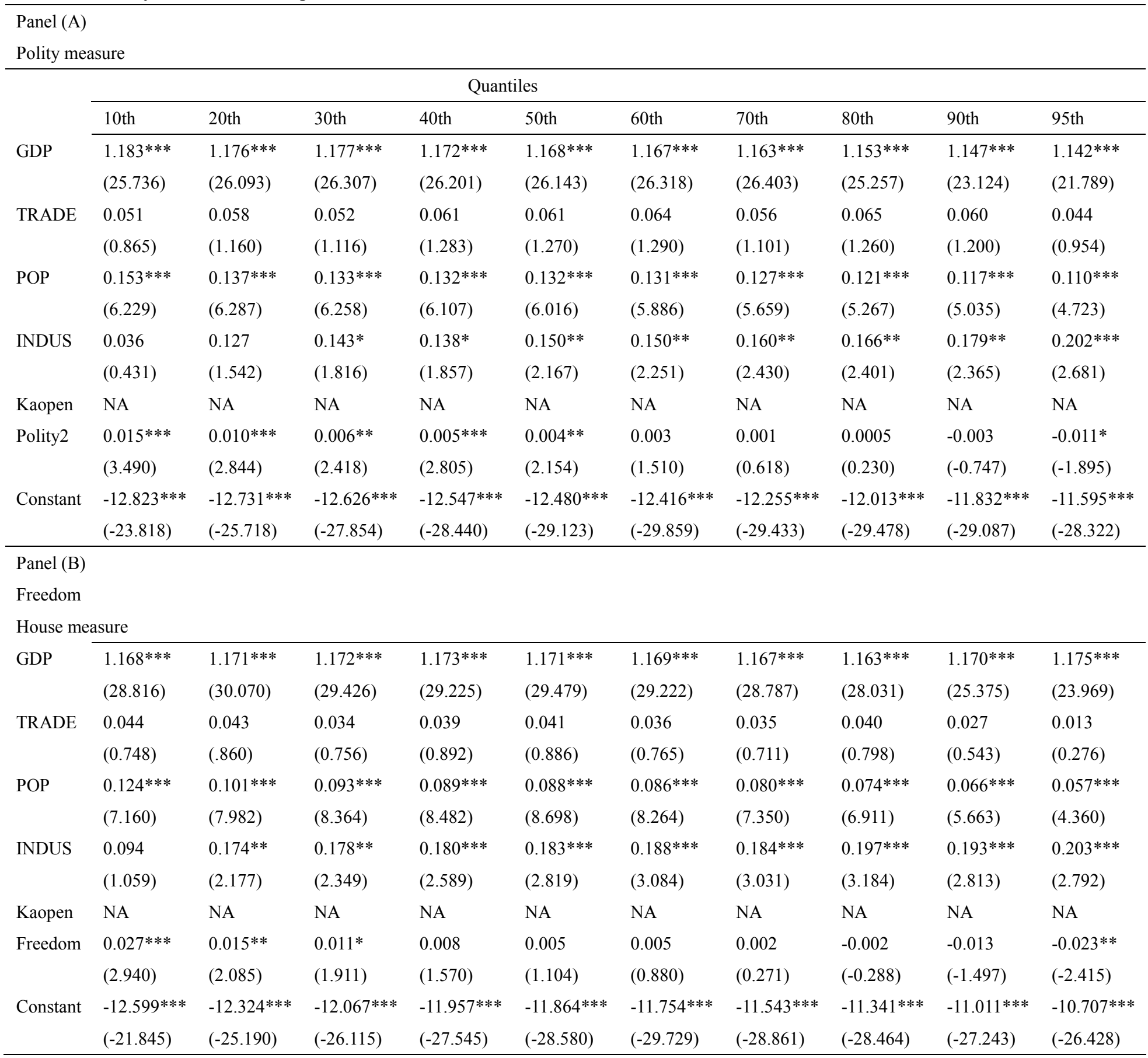

$\mathrm{t}$ values in parentheses. $*$ indicate statistical significance at $10 \%$; * indicate significance at $5 \%$ and $* * *$ indicate significance at $1 \%$. 
Table 10

Robustness alayisis: exclude democracy

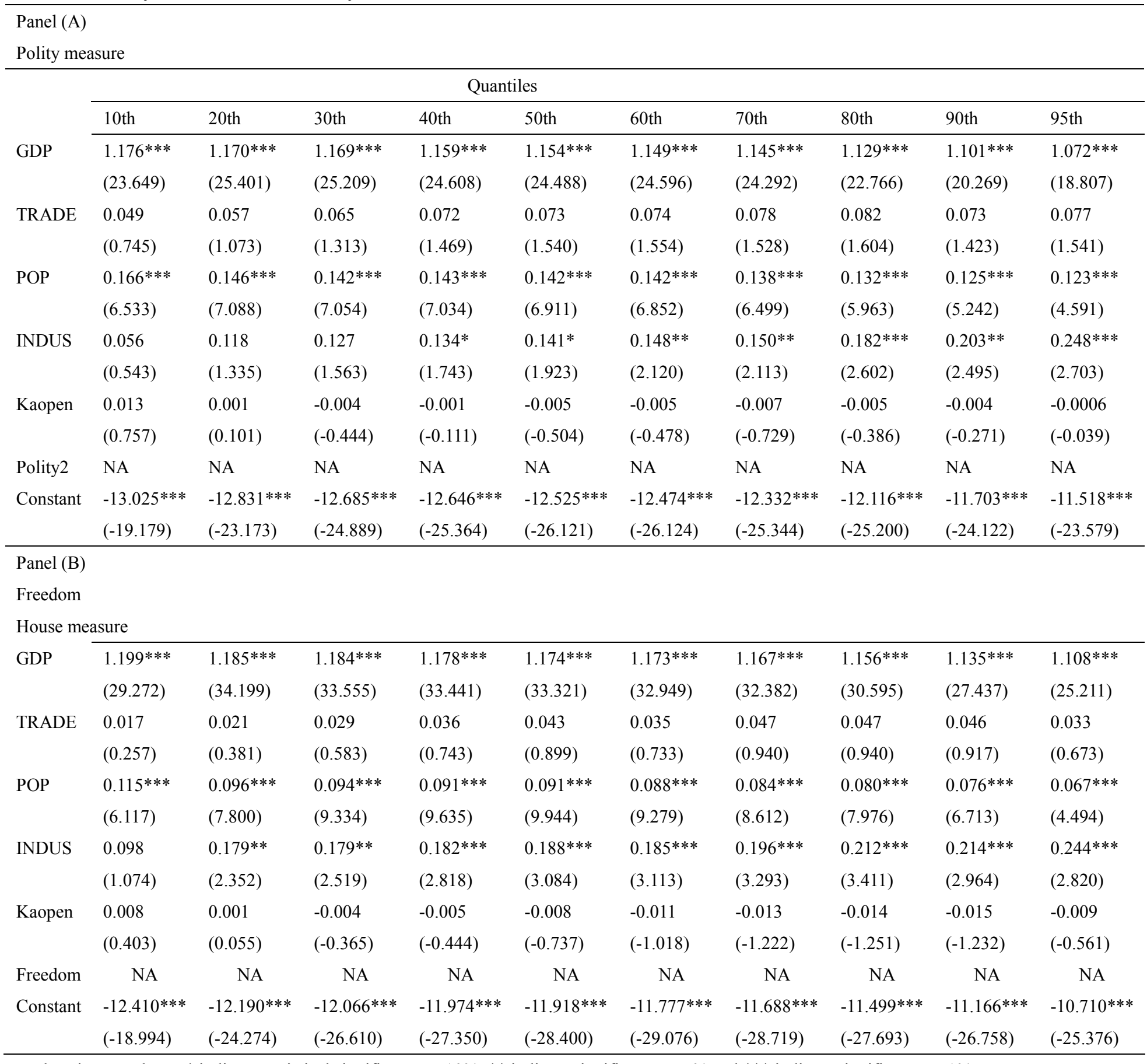

$\mathrm{t}$ values in parentheses. $*$ indicate statistical significance at $10 \%$; * indicate significance at $5 \%$ and $* * *$ indicate significance at $1 \%$. 

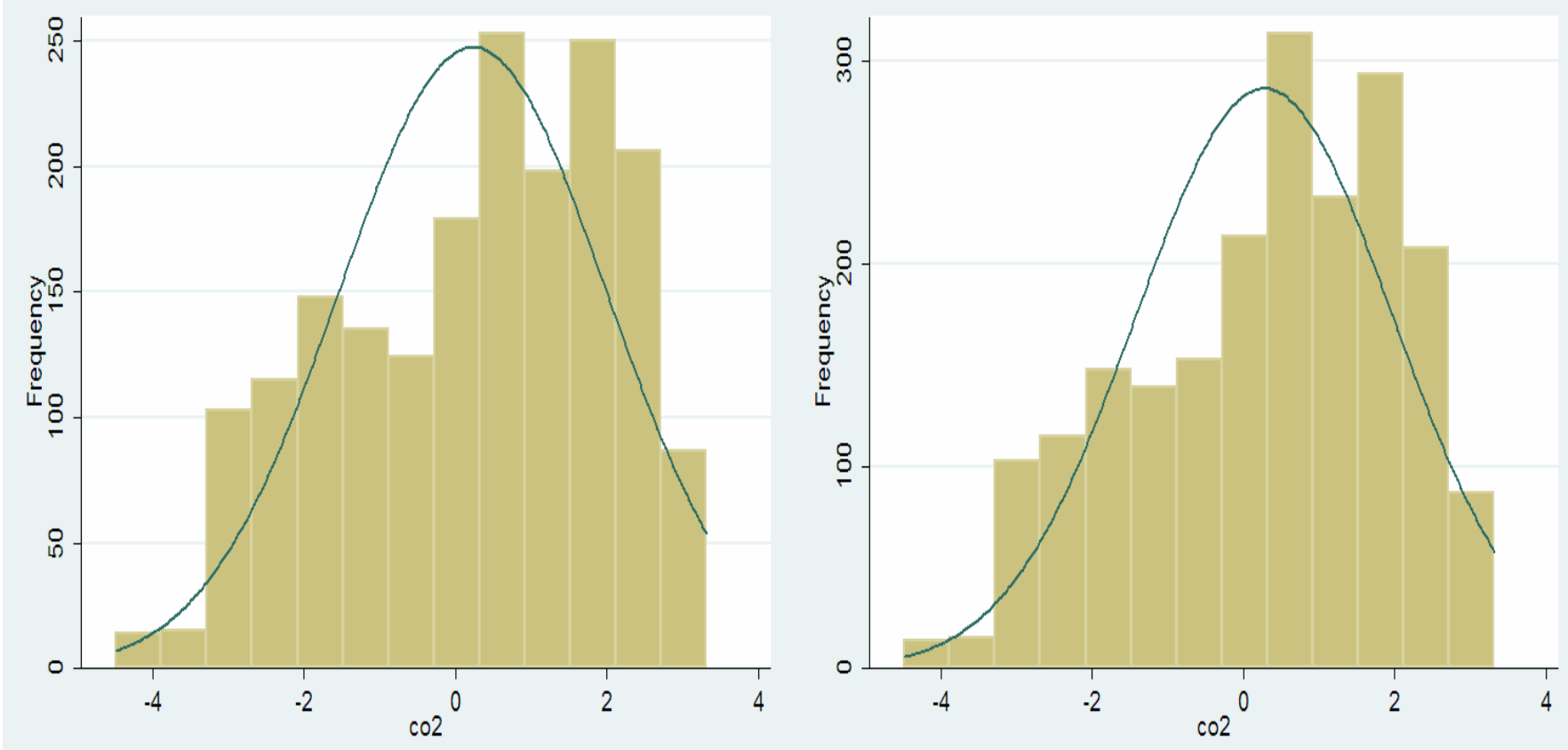

Fig.1 Histogram for $\mathrm{CO}_{2}$ emissions variable, overlaid with a best-fit Gaussian density 


\section{Appendix A}

List of countries in the sample over the period 1985-2005.

Algeria, Antigua and Barbuda*, Argentina, Australia, Austria, Bangladesh, Barbados*, Belgium, Belize*, Benin, Bhutan, Bolivia, Botswana, Brazil, Burundi, Cameroon, Canda, Cape Verde, Central African Republic, Chad, Chile, China, Colombia, Comoros, Democratic Republic of Congo, Republic of Congo, Costa Rica, Cote d'Ivoire", Cypruse ${ }^{+}$, Denmark, Dominica*, Dominican Republic, Ecuador, Egypt, Equatorial Guinea, Ethiopia, Fiji, Finland, France, Gabon, Gambia, Ghana, Grenada*, Guyana, Honduras, Iceland*, India, Indonesia, Iran Islamic Rep, Italy, Japan, Jordan, Kenya, South Korea, Madagascar, Malawi, Malaysia, Mali, Malta*, Mauritania, Mauritius, Mexico, Morocco, Nepal, Netherlands, New Zealand, Norway, Pakistan, Panama, Philippines, Portugal, Rwanda, Saudi Arabia, Senegal, Seychelles*, Sierra Leone, Singapore, South Africa, Spain, Sri Lanka, St.Lucia ${ }^{*}$, St.Vincent and the Grenadines ${ }^{*}$, Sudan, Suriname, Swaziland, Sweden, Syrian Arab Republic, Thailand, Togo, Trinidad and Tobagao, Tunisia, Turkey, Uganda, United Kingdom, United States, Uruguay, Venezuela RB, Zanvua.

* Not included in Polity measure

+ Not included in Freedom House measure 